\title{
Evaluation of Phosphodiesterase-5 Inhibitory Potential of Biofield Energy Treated DMEM by Determining cGMP Level in Human Endothelial Cell Line
}

\author{
Alice Branton ${ }^{1}$ and Snehasis Jana ${ }^{2 *}$ \\ ${ }^{1}$ Trivedi Global, Inc., India \\ ${ }^{2}$ Trivedi Science Research Laboratory Pvt. Ltd., India \\ *Corresponding author: Snehasis Jana, Trivedi Science Research Laboratory Pvt. Ltd, Bhopal- 462026 Madhya Pradesh, India
}

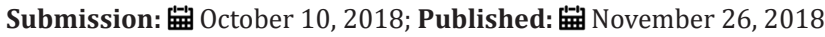

\begin{abstract}
Erectile dysfunction is a common disorder found in men, which occurs due to multiple factors such as psychogenic, hormonal imbalance, and neurovascular disturbances. The present investigation was undertaken to examine the effect of a Consciousness Energy Healing based DMEM medium on the Human Endothelial Hybrid Cell Line (EA. hy926) to evaluate the level of cyclic guanosine monophosphate (cGMP). The test item (DMEM medium) was divided into three parts, first part received a one-time Consciousness Energy Healing Treatment by a renowned Biofield Energy Healer, Alice Branton and was labeled as the one-time Biofield Energy Treated (BT-I) DMEM, while second part received the two-times the Biofield Energy Treatment and is denoted as BT-II DMEM. The third part did not receive any treatment and defined as the untreated DMEM group. The level of cGMP for the inhibition of PDE-5 enzyme was assessed using cGMP ELISA assay kit (colorimetric). Sildenafil citrate, used as positive control, which showed a significant increase of cGMP levels in Ea. hy926 cells. The one-time Biofield Energy Healing Treated DMEM (BT-I) showed 29.92\% alteration, while the two-times Biofield Energy Healing Treated DMEM (BT-II) showed a significantly $(p \leq 0.001)$ increased level of intracellular cGMP by 307.09\% in Ea. hy 926 cells compared to the untreated DMEM group. Overall, experimental data suggested that the two-times Biofield Treated DMEM showed a significantly improved level of cGMP compared with the one-time Biofield Treated DMEM group. Therefore, data indicated that the Biofield Energy Healing Treatment can be used to treat erectile dysfunction along with other sexual disorders such as orgasmic disorders, female sexual arousal disorder, fetishistic disorder, frotteuristic disorder, hypoactive sexual desire disorder, sex addiction, sexual masochism and sadism, vaginismus, voyeuristic disorder, premature or delayed ejaculation.
\end{abstract}

Keywords: Biofield energy; The Trivedi effect ${ }^{\circledR}$; cGMP; PDE-5; Sexual disorders; Endothelial hybrid cell; DMEM; Erectile dysfunction

Abbreviations: BT-I: One-time Biofield Energy Treatment, BT-II: Two-times Biofield Energy Treatment, CAM: Complementary and Alternative Medicine, NCCAM: National Center for Complementary and Alternative Medicine; DMEM: Dulbecco's Modified Eagle's Medium; cGMP: Cyclic Guanosine 3',5'-Monophosphate; FBS: Fetal Bovine Serum

\section{Introduction}

More than 30 million men in the United States and far more all over the world have erectile dysfunction (ED), which is a pervasive disorder and a most common disability. Very few are seeking medical attention, and even fewer have received minimal benefits from modern pharmaceutical based therapy [1]. ED is the incapability of the person for satisfactory sexual intercourse to achieve or maintain a penile erection [2]. Vascular, neurogenic, hormonal, and psychological factors play an important role for a penile erection or its dysfunction [3]. Impaired function of arteries and corpora cavernosa within penis are the major condition for impotence, while lack of smooth muscle tone and imperfections in neuronal stimuli can lead to unsuccessful penile erection [4]. ED eventually leads to other associated cardiovascular and neuronal diseases such as atherosclerosis and diabetes [5,6]. Nitric oxide synthase (NOS) enzymes play the significant role in the mechanism of ED. It enhances the production of cyclic guanosine monophosphate (cGMP), which results in smooth muscle relaxation and vasodilation via NO/cGMP pathway $[7,8]$. Insufficient level of NO/cGMP leads to ED. Thus, cGMP is the major therapeutically important target to overcome ED by inhibiting the cGMP-specific phosphodiesterase (PDE-5) enzyme [9]. However, at present various synthetic drugs are available like sildenafil, a well-known PDE5 inhibitor to treat ED but associated with life-threatening sideeffects like hypotension and cardiac arrhythmia [10], and vascular or neuronal deficiency like diabetes [11]. Thus, some alternative or complementary therapeutic approach is very much required to treat impotence without any side-effects. 
Complementary and Alternative Medicine (CAM) therapies have shown various significant clinical benefits. Over the past few decades, many energy healing practices have reported significant outcomes in various clinical and non-clinical fields. The effects of the CAM therapies have great potential, which include external qigong, Johrei, Reiki, therapeutic touch, yoga, Qi Gong, polarity therapy, Tai Chi, panic healing, deep breathing, chiropractic/ osteopathic manipulation, guided imagery, meditation, massage, homeopathy, hypnotherapy, progressive relaxation, acupressure, acupuncture, special diets, relaxation techniques, Rolfing structural integration, healing touch, movement therapy, Pilates, mindfulness, Ayurvedic medicine, traditional Chinese herbs and medicines in biological systems both in vitro and in vivo [12]. All living organisms possess some unique energy known as "Biofield Energy", which is an infinite, para-dimensional and electromagnetic field surrounding the human body. "Biofield" (Putative Energy Fields) based Energy Healing Therapies have been reported to have significant outcomes against various disease conditions. Biofield Energy Healing Treatment (The Trivedi Effect ${ }^{\circledR}$ ) contains putative bioenergy, which is channeled by a renowned practitioner from a distance. Biofield Energy Healing as a CAM showed a significant result in biological studies [13]. However, the National Center for Complementary and Alternative Medicine (NCCAM), well-defined Biofield Therapies in the subcategory of Energy Therapies [14]. The Trivedi Effect $^{\circledR}$ - Consciousness Energy Healing Treatment has been reported to have created significant changes in the physicochemical properties of metals, chemicals, ceramics and polymers [15-17], improved agricultural crop yield, productivity, and quality [18,19],transformed antimicrobial characteristics [2022], biotechnology [23,24], improved bioavailability [25-27], skin health [28,29], nutraceuticals [30,31], cancer research [32,33], bone health [34-36], human health and wellness. From outstanding benefits of Biofield Energy Treatment, the present study aimed to evaluate the impact of the Biofield Energy Treated (The Trivedi Effect $^{\circledR}$ ) DMEM on ED using the standard in vitro assay in Human Endothelial Hybrid Cell Line (EA. hy926) cells.

\section{Material and Methods}

\section{Chemicals and reagents}

Sildenafil citrate was purchased from Clearsynth, India. Fetal bovine serum (FBS) and Dulbecco's Modified Eagle's Medium (DMEM) were purchased from Life Technology, USA. Antibiotics solution (penicillin-streptomycin) was procured from HiMedia, India, and ethylenediaminetetraacetic acid (EDTA) was purchased from Sigma, USA. All the other chemicals used in this experiment were analytical grade procured from India.

\section{Cell culture}

Human Endothelial Hybrid Cell Line (EA. hy926) was used as a test system in the present study. The EA. hy926 cell line was maintained in DMEM growth medium for routine culture supplemented with 10\% FBS. Growth conditions were maintained at $37^{\circ} \mathrm{C}, 5 \% \mathrm{CO}_{2}$, and $95 \%$ humidity and subculture by trypsinization followed by splitting the cell suspension into fresh flasks and supplementing with fresh cell growth medium. Three days before the start of the experiment, the growth medium of near-confluent cells was replaced with fresh phenol-free DMEM, supplemented with $10 \%$ charcoal-dextran stripped FBS (CD-FBS) and $1 \%$ penicillin-streptomycin [37].

\section{Experimental design}

The experimental groups consisted of group 1 (G-I) with serum-free DMEM defined as the untreated DMEM group. Group 2 (G-II) consisted of positive control (sildenafil citrate) at different concentrations. Further, group 3 (G-III) included DMEM medium (test item group) with the one-time Biofield Energy Treatment and denoted as the BT-I, while group 4 (G-IV) included the test item with the two-times Biofield Energy Treatment and denoted as the BT-II.

\section{Consciousness energy healing treatment strategies}

The test item, DMEM was divided into three parts. One part of the test item was treated with the one-time Biofield Energy Healing Treatment by a renowned Biofield Energy Healer (The Trivedi Effect ${ }^{\circledR}$ ) and coded as the Biofield Energy Treated DMEM (BT-I), while the second part was received the two-times Biofield Energy Healing Treatment and denoted as the BT-II DMEM. Further, the third part did not receive any treatment and defined as the untreated DMEM group. This Biofield Energy Healing Treatment was provided by a renowned Biofield Energy Healer, Alice Branton, remotely for $\sim 5$ minutes. The Biofield Energy Healer was located in the USA, while the test item was located in the research laboratory of Dabur Research Foundation, New Delhi, India. This Biofield Energy Treatment was administered for $\sim 5$ minutes through the Healer's unique Energy Transmission process remotely to the test items under the standard laboratory conditions. Alice Branton never visited the laboratory in person, nor had any contact with the test item (DMEM medium). Further, the untreated DMEM group was treated with a "sham" healer for comparative purposes. The "sham" healer did not have any knowledge about the Biofield Energy Treatment. After that, the Biofield Energy Treated and untreated samples were kept in similar sealed conditions for experimental study.

\section{Assessment of PDE-5 enzyme inhibition}

The cells were counted using an hemocytometer and were seeded at a density of 0.4 X 106 cells/well in DMEM with $10 \%$ FBS in 6-well plates. Cells were incubated in a $\mathrm{CO} 2$ incubator for 24 hours at $37{ }^{\circ} \mathrm{C}, 5 \% \mathrm{CO}$, and 95\% humidity. After 24 hours of incubation, the medium was replaced with DMEM+1\% FBS followed by treatment with the test item (Biofield Energy Treated DMEM). Sildenafil citrate was used as a positive control. After incubation for 24 hours, cell lysates were prepared (as per the ELISA kit instructions). The effect of the test item on modulation of intracellular cGMP level, if any, in Ea. hy926 cells were assessed using colorimetric cGMP ELISA kit as per manufacturer instruction. The samples were detected for cGMP assay in triplicates. The absorbance of each well was measured at $450 \mathrm{~nm}$ immediately. Increase in cGMP level was determined using equation (1)

\% Increase in intracellular cGMP level $=\{(B-A) / A\} \times 100----$ $--(1)$ 
Where, $\mathrm{B}=$ Optical density (OD) of the cells treated with the test item and $A$ is the OD of the untreated DMEM $[38,39]$.

\section{Statistical analysis}

All the values were represented as Mean \pm SEM of intracellular cGMP levels of three independent experiments. For multiple group comparison, one-way analysis of variance (ANOVA) was used followed by post-hoc analysis by Dunnett's test. Statistically significant values were set at the level of $p \leq 0.05$.

\section{Results and Discussion}

\section{Estimation of the effect of test item on PDE-5 enzyme inhibition}

The results of the intracellular cGMP levels in Ea. hy926 cells are shown in Figure 1. Sildenafil citrate as a positive control at $25 \mu \mathrm{M}$, $50 \mu \mathrm{M}$, and $100 \mu \mathrm{M}$ demonstrated significant increased intracellular cGMP level in Ea. hy 926 cells by $34 \%, 84 \%$, and $234 \%$, respectively compared to the untreated DMEM group (cGMP values defined as 100\%). The one-time Biofield Energy Treated test item (BT-I) and the untreated DMEM showed almost a similar concentration of cGMP $(0.89 \mathrm{pmol} / \mathrm{mL})$, while the two-times Biofield Energy Treated group (BT-II) showed a significant increase the level of intracellular cGMP concentration by $307.09 \%$ compared to the untreated DMEM group. Therefore, the two-times Biofield Energy Treated DMEM group demonstrated a significant increase in the intracellular cGMP level in Ea. hy926 cells compared to untreated DMEM group. Thus, the data suggested that two-times Consciousness Energy Healing Treatment has significantly improved the cGMP level, which could help to resolve the erectile dysfunction related disorders (Figure 1) It might be expected that Biofield Energy Healing Treatment can mediate the smooth muscle relaxation that might increase the level of cGMP. The smooth muscles, nerves, and endothelial cells might stimulate guanylyl cyclase (GC) to produce cGMP and thus results in lowers intracellular calcium levels, which results in penile erection $[40,41]$. PDE-5 is the predominant phosphodiesterase in the corpus cavernosum. In this experiment, the Biofield Energy Treatment helps to increase the level of endogenous cGMP by inhibiting its breakdown by the PDE-5 enzyme [42].

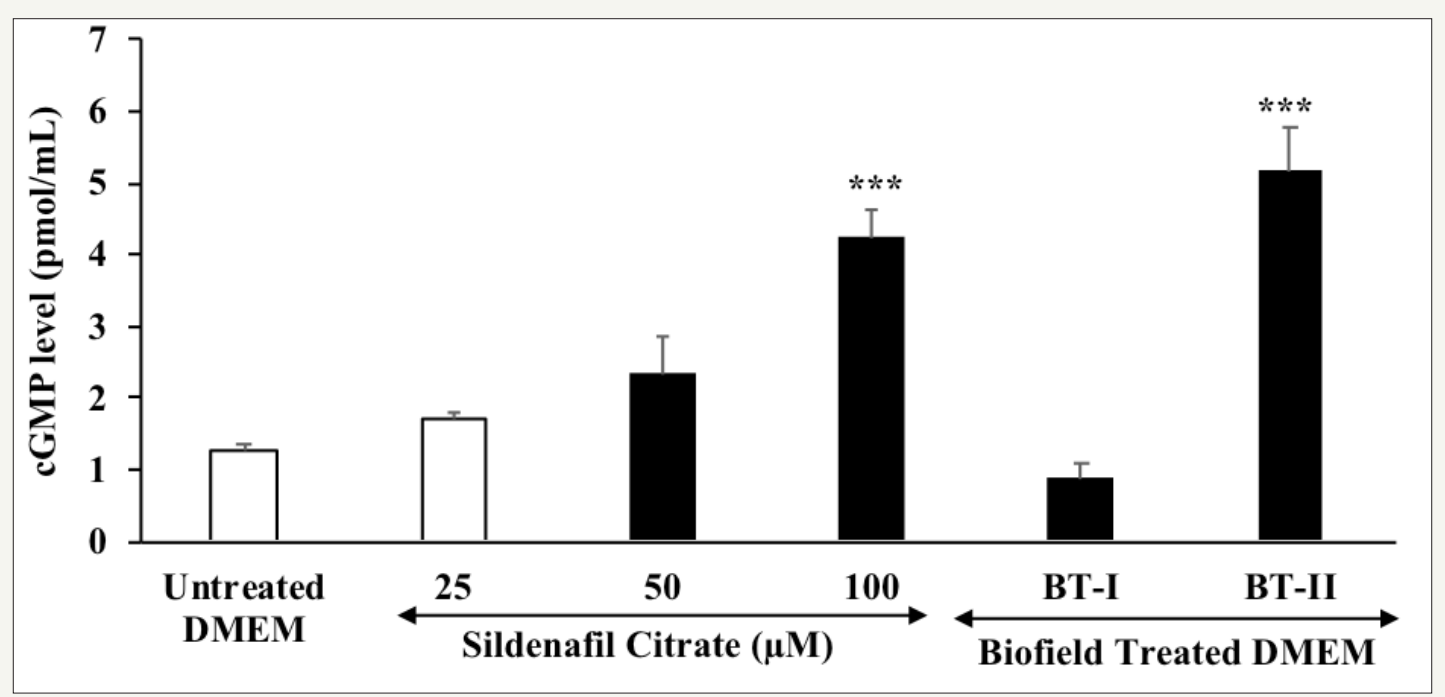

Figure 1: Effect of the Biofield Energy Treated test item (DMEM) on the level of intracellular cyclic guanosine monophosphate (cGMP) in human endothelial hybrid (Ea. hy 926) cells.

Data were expressed as Mean \pm SEM of three independent experiments.

BT-I: One-time Biofield Energy Treatment; BT-II: Two-times Biofield Energy Treatment

${ }^{* * *} p \leq 0.001$ compared to the untreated DMEM group

\section{Conclusion}

Erectile dysfunction is a common, multifactorial disorder, which is associated with a wide number of factors such as aging, organic and psychogenic conditions such as hypertension, hypercholesterolemia, diabetes mellitus, cardiovascular disease, and depression. Modern therapy is not attractive due to its lot of life-threating side-effects. Thus, Biofield Energy Healing Therapy can be used to treat erectile dysfunction (ED). The study results showed that the two-times Biofield Energy Treated DMEM significantly $(p \leq 0.001)$ increased the level of the intracellular cGMP levels by $307.09 \%$ in the Ea. hy926 cells compared to the untreated DMEM group. The Biofield Energy Treated (The Trivedi
Effect $^{\circledR}$ ) DMEM has significant impact on cGMP level, which might be due to the significant inhibition of the PDE-5 enzyme. Therefore, the Consciousness Energy Healing Therapy might be a suitable alternative treatment option for ED. It can also be useful for the management of various sexual disorders viz. dyspareunia, exhibitionistic disorder, female and male orgasmic disorders (delay or absence of orgasm), female sexual arousal disorder (inability to become physically aroused or excited during sexual activity), fetishistic disorder, frotteuristic disorder, hypoactive sexual desire disorder, sex addiction, vaginismus, premature or delayed ejaculation (or sexual malfunction or sexual disorder) improve normal sexual activity, including physical pleasure, desire, preference, arousal or orgasm, desire disorders (lack of sexual 
desire or interest in sex), and neurological disorders, hormonal imbalances, sexual performance, marital or relationship problems, effects of a past sexual trauma, depression, feelings of guilt, pain disorders (pain during intercourse).

\section{Acknowledgement}

Authors are grateful to Dabur Research Foundation, Trivedi Global, Inc., Trivedi Science, Trivedi Testimonials, and Trivedi Master Wellness for their support throughout the work.

\section{Conflict of Interest}

Authors declare that there was no conflict of interest.

\section{References}

1. McKinlay JB (2000) The worldwide prevalence and epidemiology of erectile dysfunction. Int J Impot Res 12(4): S6-S11.

2. Consensus development conference statement (1993) National Institutes of Health. Impotence. Int J Impot Res 5(4): 181-284.

3. National Institutes of Health Consensus Conference (1993) Impotence NIH consensus development panel on impotence. JAMA 270 (1): 83-90.

4. Dean RC, Lue TF (2005) Physiology of penile erection and pathophysiology of erectile dysfunction. Urol Clin North Am 32(4): 379395.

5. Billups KL (2005) Sexual dysfunction and cardiovascular disease: Integrative concepts and strategies. Am J Cardiol 96: 57-61.

6. Thorvea VS, Kshirsagara AD, Vyawaharea NS, Joshib VS, Ingalea KG, et al. (2011) Diabetes-induced erectile dysfunction: epidemiology, pathophysiology and management. J Diabetes Complications 25(2): 129-136.

7. Burnett AL (2002) Nitric oxide regulation of penile erection: Biology and therapeutic implications. J Androl 23: S20-S26.

8. Morelli A, Filippi S, Vignozzi L, Mancina R, Maggi M (2006) Physiology of erectile function: An update on intracellular molecular processes. EAUEBU Update Ser 4(3): 96-108.

9. Andersson KE (2011) Mechanisms of penile erection and basis for pharmacological treatment of erectile dysfunction. Pharmacol Rev 63(4): 811-859.

10. Chamsi Pasha H (2001) Sildenafil (Viagra) and the heart. J Fam Community Med 8(2): 63-66.

11. Doggrell S (2007) Do vardenafil and tadalafil have advantages over sildenafil in the treatment of erectile dysfunction? Int J Impot Res 19(3): 281-295.

12. Rubik B (2002) The biofield hypothesis: Its biophysical basis and role in medicine. J Altern Complement Med 8(6): 703-717.

13. Barnes PM, Bloom B, Nahin RL (2008) Complementary and alternative medicine use among adults and children: United States, 2007. Natl Health Stat Report 12: 1-23.

14. Frass M, Strassl RP, Friehs H, Müllner M, Kundi M, et al. (2012) Use and acceptance of complementary and alternative medicine among the general population and medical personnel: A systematic review. Ochsner J 12(1): 45-56

15. Trivedi MK, Tallapragada RM (2008) A transcendental to changing metal powder characteristics. Met Powder Rep 63: 22-28, 31.

16. Trivedi MK, Nayak G, Patil S, Tallapragada RM, Latiyal O (2015) Studies of the atomic and crystalline characteristics of ceramic oxide nano powders after bio field treatment. Ind Eng Manage 4: 161.

17. Trivedi MK, Nayak G, Patil S, Tallapragada RM, Latiyal O, et al. (2015)
Effect of biofield energy treatment on physical and structural properties of calcium carbide and praseodymium oxide. International Journal of Materials Science and Applications 4(6): 390-395.

18. Trivedi MK, Branton A, Trivedi D, Nayak G, Mondal SC, et al. (2015) Morphological characterization, quality, yield and DNA fingerprinting of biofield energy treated alphonso mango (Mangifera indica L.). Journal of Food and Nutrition Sciences 3: 245-250.

19. Trivedi MK, Branton A, Trivedi D, Nayak G, Mondal SC, et al. (2015) Evaluation of biochemical marker - Glutathione and DNA fingerprinting of biofield energy treated Oryza sativa. American Journal of Bio Science 3: $243-248$

20. Trivedi MK, Branton A, Trivedi D, Nayak G, Charan S, et al. (2015) Phenotyping and 16S rDNA analysis after biofield treatment on Citrobacter braakii: A urinary pathogen. J Clin Med Genom 3: 129.

21. Trivedi MK, Patil S, Shettigar H, Mondal SC, Jana S (2015) Evaluation of biofield modality on viral load of Hepatitis B and C viruses. J Antivir Antiretrovir 7: 83-88.

22. Trivedi MK, Patil S, Shettigar H, Mondal SC, Jana S (2015) An impact of biofield treatment: Antimycobacterial susceptibility potential using BACTEC 460/MGIT-TB System. Mycobact Dis 5: 189.

23. Trivedi MK, Patil S, Shettigar H, Bairwa K, Jana S (2015) Phenotypic and biotypic characterization of Klebsiella oxytoca: An impact of biofield treatment. J Microb Biochem Technol 7: 203-206.

24. Nayak G, Altekar N (2015) Effect of biofield treatment on plant growth and adaptation. J Environ Health Sci 1: 1-9.

25. Branton A, Jana S (2017) The influence of energy of consciousness healing treatment on low bioavailable resveratrol in male Sprague Dawley rats. International Journal of Clinical and Developmental Anatomy 3: 9-15.

26. Branton A, Jana S (2017) The use of novel and unique biofield energy healing treatment for the improvement of poorly bioavailable compound, berberine in male Sprague Dawley rats. American Journal of Clinical and Experimental Medicine 5: 138-144.

27. Branton A, Jana S (2017) Effect of the biofield energy healing treatment on the pharmacokinetics of 25-hydroxyvitamin D3 [25(OH)D3] in rats after a single oral dose of vitamin D3. American Journal of Pharmacology and Phototherapy 2: 11-18.

28. Kinney JP, Trivedi MK, Branton A, Trivedi D, Nayak G, et al. (2017) Overall skin health potential of the biofield energy healing-based herb mineral formulation using various skin parameters. American Journal of Life Sciences 5: 65-74

29. Singh J, Trivedi MK, Branton A, Trivedi D, Nayak G, et al. (2017) Consciousness energy healing treatment-based herb mineral formulation: A safe and effective approach for skin health. American Journal of Pharmacology and Phytotherapy 2: 1-10.

30. Trivedi MK, Branton A, Trivedi D, Nayak G, Plikerd WD, et al. (2017) A Systematic study of the biofield energy healing treatment on physicochemical, thermal, structural, and behavioral properties of magnesium gluconate. International Journal of Bioorganic Chemistry 2: 135-145.

31. Trivedi MK, Branton A, Trivedi D, Nayak G, Plikerd WD, et al. (2017) Chromatographic and spectroscopic characterization of the consciousness energy healing treated Withania somnifera (ashwagandha) root extract. European Journal of Biophysics 5: 38-47.

32. Trivedi MK, Patil S, Shettigar H, Mondal SC, Jana S (2015) The potential impact of biofield treatment on human brain tumor cells: A time-lapse video microscopy. J Integr Oncol 4: 141.

33. Trivedi MK, Patil S, Shettigar H, Gangwar M, Jana S (2015) In vitro evaluation of biofield treatment on cancer biomarkers involved in endometrial and prostate cancer cell lines. Cancer Science \& Therapy 7(8): 253-257. 
34. Anagnos D, Trivedi K, Branton A, Trivedi D, Nayak G, et al. (2018) Influence of biofield treated vitamin D3 on proliferation, differentiation, and maturation of bone-related parameters in MG-63 cell-line. International Journal of Biomedical Engineering and Clinical Science 4: 6-14.

35. Lee AC, Trivedi K, Branton A, Trivedi D, Nayak G, et al. (2018) The potential benefits of biofield energy treated vitamin $\mathrm{d} 3$ on bone mineralization in human bone osteosarcoma cells (MG-63). International Journal of Nutrition and Food Sciences 7: 30-38.

36. Stutheit ME, Trivedi K, Branton A, Trivedi D, Nayak G, et al. (2018) American Journal of Life Sciences 6: 13-21.

37. Lu H, Li X, Zhang J, Shi H, Zhu X, et al. (2014) Effects of cordycepin on HepG2 and EA. hy926 cells: Potential antiproliferative, antimetastatic and anti-angiogenic effects on hepatocellular carcinoma. Oncol Lett 7(5): 1556-1562.
38. Corbin JD, Francis SH (1999) Cyclic GMP phosphodiesterase-5 target of sildenafil. J Biol Chem 274(20): 13729-13732.

39. De Young L, Yu D, Freeman D, Brock GB (2003). Effect of PDE5 inhibition combined with free oxygen radical scavenger therapy on erectile function in a diabetic animal model. Int J Impot Res 15(5): 347-354.

40. Burnett AL (2006) The role of nitric oxide in erectile dysfunction: Implications for medical therapy. J Clin Hypertens (Greenwich) 8: 53-62.

41. Corbin JD (2004) Mechanisms of action of PDE5 inhibition in erectile dysfunction. Int J Impot Res 16: S4-7.

42. Corona G, Mondaini N, Ungar A, Razzoli E, Rossi A et al. (2011) Phosphodiesterase type 5 (PDE5) inhibitors in erectile dysfunction: The proper drug for the proper patient. J Sex Med 8(12): 3418-3432.

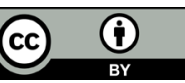

Creative Commons Attribution 4.0

International License

For possible submissions Click Here
Submit Article

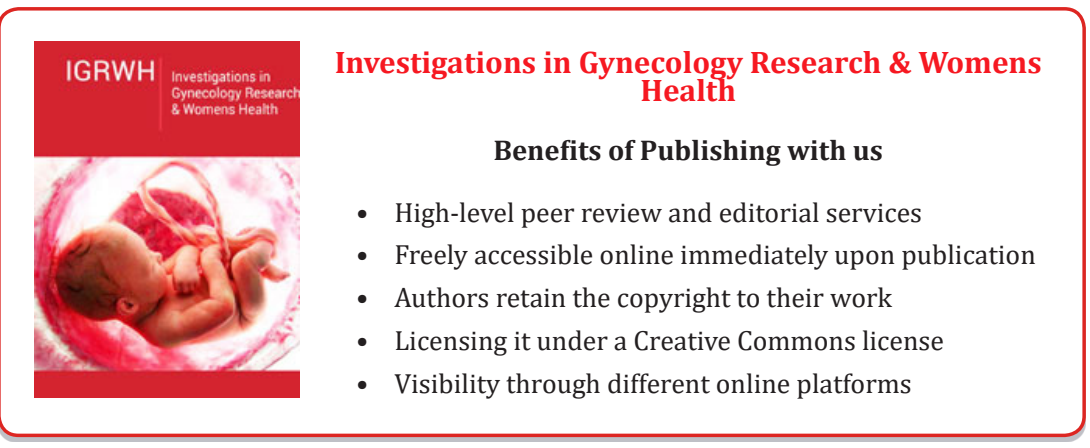

